\title{
The Native American Canoe-wright and Mariner
}

\section{Louis Arthur Norton}

Les explorateurs européens ont rencontré en Amérique du Nord les Amérindiens qui ont navigué les mers et les eaux intérieures dans une grande variété de pirogues et de canoës d'écorce et de peau; vaisseaux qui demandaient une conception imaginative, une ingéniosité de construction, des compétences de navigation ainsi que force et endurance dans des plans d'eau vastes et souvent perfides. Cet article examine un certain nombre de contributions des Béothuks, Mi'kmaq, Penobscot, Abénaquis, Pennacook et autres indigènes de la NouvelleAngleterre, avec, plus au sud les Massasoit, Narragansett, Pequot, et Mohegan. L'article note également la façon dont les influences européennes ont peut-être contribué à l'évolution des canoës, et le corollaire, comment ces vaisseaux ont affectés les premières colonies en Amérique du Nord.

Shortly after the Pilgrims landed in North America they encountered a Native American who had a canoe. They successfully communicated, and the Native gave signs indicating that he had paddled the approximate hundred sea miles alone from Monhegan Island to Cape Cod. ${ }^{1}$ This required seamanship, the ability to navigate and propel a vessel across large bodies of water, a high degree of technical skill not always associated with Native Americans of the eastern seaboard.

\section{The Native American at Sea}

Many indigenous tribes of Northeastern America were nomadic, spending winters near large game and summers on the coast where marine life was plentiful. ${ }^{2}$ The Beothuk who lived in what we now call Newfoundland, traveled to Nova Scotia. The Mi'kmaq migrated to Maine and competed for game and fish with the Penobscots. They were the principal tribe of the famous Wabenaki confederacy of the eastern seaboard that included the Pennacook of the Merrimac region to the south up to the St. John River on the north. The Natives of southern New England, the Massasoit, Narragansett, Pequot, and Mohegan, fished the rocky shore and islands as far as ten to fifteen miles out to sea.

1 Horace P. Beck, The American Indian as a Sea Fighter in Colonial Times (Mystic, CT: Marine Historical Association, 1920), 5.

2 John Gyles, Memoirs of Odd Adventures, Strange Deliverances \&c. In The Captivity of John Giles Esq (Boston, 1736).

The Northern Mariner/le marin du nord, XXIII No. 4, (October 2013), 399-411 
The watercrafts the indigenous people used were called canoes, a term only partly originating from aboriginal languages. The word dates from the mid-1500s, originally in a West Indian context, from Arawakan (Haiti) canaoua, the Carb word for dugout. English explorers often referred to the Native crafts as canoa. The early French explorers called these vessels canau [canaux pl.] the word for canal, perhaps because they were used on rivers and streams, long narrow canal-like waterways that took them to their destinations. Obviously the linguistic leap from canau and canoa to the word canoe was slight. The first published account of Native American bark canoe designs occurred in 1722. The earliest illustration of a bark canoe accurate enough to give evidence of its tribal designation appeared two years later. ${ }^{3}$ Complicating the study of the history of Native canoes is the fact that the indigenous people had no written language, although they did make petroglyph images. No prehistoric canoes have survived, therefore canoewright methods are known through oral histories or descriptions of the vessels found in the writings of explorers and early colonists.

Canoe design variations were an outgrowth of the Native's need to negotiate natural water highways - the rivers and streams traversing the vast forests and the ocean beyond. The streams of Maine were generally fast moving with many challenging stretches of white water. New Brunswick streams were less turbulent or slower moving thus demanding a different design. The waters of Nova Scotia were generally languid so Natives built their canoes for paddling across the Bay of Fundy to go back and forth to the Maine coast. Archeological excavations give evidence that the Native Americans inhabited Long Island, Block Island, Nantucket, Martha's Vineyard, and Monhegan Island and hunted in near coastal ocean to capture whales, porpoises and seals as well as large cod and swordfish. For those who pursued leviathans and large fish, the Natives had to be competent boat handlers, particularly in choppy seas infested by sharks. ${ }^{4}$

\section{Transports of Necessity}

Native religious beliefs influenced the function and form of canoes. Indigenous Americans were "animists" believing that the spirit world consisted of the "elements" earth, air, fire, and water. These elements formed a supernatural web of power that interconnected every aspect of their world, a biosphere filled with a complex variety of "beings" that possessed power, some animate, some inanimate and others were purely spiritual. These "beings" could be clouds, rocks, mountains, mammals, or the fish that dwelled in the inhospitable spiritual element - water. Power flowed from each giving rise to elaborate religious rituals performed to assuage, influence, flatter or in some cases trick or deceive the spiritual "keepers" of the "beings" to make them available for the Native's wellbeing.

European social values differed markedly from those of the Native Americans.

3 Ibid., 5-14.

4 Charles E. Banks, History of Martha's Vineyard (Boston: G. H. Dean, 1911), vol. VI, 340; James Rosier, A True Relation etc. in George P. Winship, Sailor's Narratives of Voyages Along The New England Coast 1524-1624 (Boston: Houghton Mifflin and Company, 1905), 148-9. 
The colonists lived and worked within fixed property boundaries fencing fields to graze privately owned animals, clearing land, planting crops, killing game and fishing for themselves. They kept the excess to provide for trade and financial gain. This could lead to ownership problems, the necessity of protecting property and punishment of thieves.

Natives did not work for wages and had no real concept of "capital exchange." The indigenous people considered owning private property within the tribe as avaricious behavior amounting to enslavement to property and the cause of greed. Theft was virtually unknown in their society. There were no locks on bark huts. Hunger occasionally troubled villages because small caches of crops often did not last through the winter, but they suffered hunger as a group. The Native Americans believed that they lived within an intricate web of nature forming beings like themselves. Their myths led to a religion of moral reciprocity. Clearly humans had to take life in order to survive, but in this uncomfortable relationship they were obligated to perform rituals to honor the spirits of the animal and plant life and not waste resources beyond the Native's needs. Therefore they only took from the earth what was needed for subsistence. Water transportation was a tool necessity; a means for efficient hunting and gathering food needed to feed their family or community.

The forest provided many varieties of trees that could be used to make canoes, but obvious constraints limited their choices. For quick transportation, small trees and brush could be lashed together as rafts or floats for navigating broader rivers and streams. Bark canoes could be made from parts of trees. For more substantial vessels like dugouts, whole trees were needed; trees that could be easily worked, located close to the water, and recently damaged by natural causes such as lightning, windstorms or beavers that only needed to be taken down. A common method for completing the felling was to start a controlled fire at its base to weaken it for cutting. The tree could then be pulled or pushed down, a difficult and dangerous process. ${ }^{5}$

Canoes were convenient for shoal-water transportation because they were relatively light with a shallow draft. Unfortunately they were easily damaged requiring repairs to the bark covers (or hull) at the end of each significant outing. Still, lightweight canoes could be carried overland for long distances on rough trails, support heavy loads in shallow and even rough water and be repaired with simple tools. The largest canoes, perhaps 30 feet long at the gunwales and 33 feet overall with up to 60 inches extreme beam, carried approximately a ton of cargo plus a crew or families moving to new habitations. The design simplicity and versatility of the Native canoes encouraged the European explorers to adopt these craft with little alteration for wilderness travel.

\section{Early Canoe History}

North American explorers noted the presence of Native canoes, but did not describe the vessels other than comment on number of persons that a canoe could safely carry and their swiftness. Samuel de Champlain was the first to attempt to record dimensions of the bark canoes. In 1603 Champlain described what appeared to be

5 Stone axes did not easily cut down large trees and once felled it was very difficult to move over smaller logs in a roller fashion. 
Algonquian canoes as being eight to nine paces long and one and one-half paces wide. Assuming a pace being about thirty inches, then the canoes would have been between 20 and 23 feet long, between 40 and 50 inches beam width. Champlain wrote that two canoes with only two paddlers passed his fully manned longboat; an impressive bit of seamanship that may have been responsible for the rapid adoption of canoes by the early French explorers in Canada. The English explorer George Weymouth noted the swiftness of bark canoes in Maine's Penobscot Bay during his voyage to North America in 1603. Native canoes with only three or four paddlers passed his ship's boat manned with four oarsmen. ${ }^{6}$

European explorers that entered the North American waters via the far north and probably first encountered the low and slender Inuit kayaks that some metaphorically called "wave-eaters." They were protected from white caps and the elements by a watertight covered deck. They were ideal for the stealthy pursuit of sea mammals and waterfowl. Highly maneuverable, quiet, swift, and stable, these hunting boats were found all over the far Northeastern coastal regions.

Each Inuit tribe in North America developed a distinctive kayak design built to meet local conditions of hunting by sea, land and for ice portage. Kayaks were between 10 and 28 feet long and narrow from about 1.5 to 2.5 feet across. They were also shallow drafted. They were constructed by first assembling a strong yet light frame. Whale, walrus and caribou bone was plentiful, made good strong frame material and could easily be drilled through to make lashing points. By contrast wood near or above the tree line was fir, pine, or spruce usually in the form of driftwood. The frame could be of bone, wood or combinations of both. Seal or sea lion hides were stripped of fur, soaked than stretched over the ridged frame and secured with strips of animal hide or pliable sinew. The seams were overlapped, tightly sewn with sinew thread stitched in an outside to inside pattern called a "siliak," reinforced with a secondary whip-stitch, and covered with seal fat as waterproofing. The kayakers sat in manholes secured with watertight usually sealskin jackets that were fastened to the rim, their legs extended beneath the deck. Double-bladed paddles propelled their kayaks and lashed to the deck were weapons as well as other devices needed for the hunt.

Kayaks could be easily carried over the ice to access to the open water and durable enough for use in rough seas. When not in use the kayaks were stored upside down on high racks in the villages to prevent the dogs from chewing and damaging the dried skin covers.

Like most Native vessels, design variations were dictated by unique functional needs. Nunivak Islanders, who traveled far for their hunting, used a two-man tandem designed kayak. The Inuit of Baffin Island, northern Quebec and Labrador used beamy and flat-bottomed relatively stable kayaks. In addition they had high bows to override the formidable waves of the open ocean. Baffin Island "retrieval" kayaks were specially designed to be shorter than they sea kayaks to navigate around ice floes and aggregated

6 Edwin Tappan Adney and Howard I. Chapelle, The Bark Canoes and Skin Boats of North America (Washington, 1964), 7. 
pack ice to collect or tow heavy seals for butchering.

The Inuit people also developed a large Arctic skin boat called the umiak [umiaq] that was wider and deeper than the kayak, without decking and capable of carrying heavy loads of passengers and equipment. The skin-over-frame construction methods were similar to that of the kayak, but dense walrus hide, as opposed to seal and sea lion, was usually used as the frame covering. Women were often recruited to paddle umiaks during the migratory passages, but when it came to dangerous whaling, umiaks were propelled by men. Like the kayaks, the umiak could be overturned on a beach and serve as a temporary shelter in foul weather.

On the fringes of the arctic regions the wooden canoe was developed with a light inner framework, a large carrying capacity and minimum weight. This was ideal for travel on the network of lakes and rivers that stretched across the forested Northeastern part of the American continent. Wooden canoes were built with a different basic design philosophy compared with Arctic skin boats. Kayaks and umiaks were built over solid frameworks while canoes had a ribbed framing system that was forced into a bark casing giving the hull substantial stiffness. The rib pressure against the bark cover kept the hull from collapsing. At the same time, like the watercraft of the far north, canoes used offshore had to have strength in choppy seas and lightness for being hauled far ashore to prevent them from being carried away by tides and/or unexpected storms.

\section{The Beothuk Canoes of Newfoundland and Cape Breton}

The Beothuk of Newfoundland used the most unusual and visually radical of all the bark canoe designs. They reached about 14 feet in length with a beam of about 4 feet. The stem and stern were plumb without the usual flare. The cross section of the hull was constructed in a "V" shape and therefore lacked a tumblehome above the waterline. (A tumblehome measurement is the amount the sides of the canoe tip inwards toward the centerline from the maximum beam of the vessel.) A unique feature was a small rocker keel and raised section amidships on the two sides that strengthened the canoe to prevent hogging. (Hogging occurs when the bow and stern have drooped with respect to a vessel's bottom, making that bottom appear convex.) Because of this design, they were prone to capsizing therefore stone ballast was added and stabilized with bulky moss to prevent the stones from shifting in rolling seas. The result was a stable deep-draft seagoing canoe. ${ }^{7}$

\section{The Canoes of Maine, New Brunswick and Nova Scotia}

Mi'kmaq canoes were constructed in one of three general styles: all wood, large river craft, and war-canoes. The Mi'kmaq canoe had a very pronounced tumblehome and a high rounded bow and stern section that was set off by pronounced reverse curves to effectively keep the surging sea at bay. It was also flat-bottomed, but lacked both the keel and ballast of the Beothuk canoes. Its shoal draft was good for navigating in shallow

7 James P. Howley, The Beothuks or Red Indians (Cambridge: Cambridge University Press, 1915), 32-33. 
waters, but was unstable when loaded with many men or heavy bulky cargo.

The Mi'kmaq tribe identified the largest birch trees and removed the bark over the length of the canoe they hoped to build the more common 20-foot vessel. The paperwhite birch was the most frequently used hull material because it could be peeled in a relatively unblemished fashion in large resinous sheets that resisted shrinkage, could be stretched and were easily sown. The breadth was about two feet amidships and diminishing towards the bow and stern. The bark was rolled out into sheets. "Gores"(perpendicular slices made along both sides of the bark at regular intervals) were made in order to produce a curved hull turned up smoothly around the building frame. The gunwale height was roughly determined by the height of an average brave's armpits when seated. Long, lightweight and easily split cedar slats strengthened the length of the canoe, some up to four inches broad in the middle, tapering at their ends. Green cedar strips were also heated in a fire so they could be bent into half circles to form the frames. The flexible cedar frame was laid out into a rough canoe-shape and length, bound by black spruce roots, willow bows or rawhides lashing, and then stretched into the desired shape by white cedar crossbars. This was made fast and placed over rolls of bark that would eventually become its skin. Short-paired stake poles were driven into the ground next to the frame that was weighted down with heavy stones. The stake pairs were tied together to become a clamp that lashed the frame to the outer surface or skin. Holes were then made in the wooden strips or bark by bone awls or bow drills. Longer black spruce roots were soaked in water to increase their flexibility and shaved to points so they could became a thread or lacing for sewing the bark skin pieces together as well as lashings to hold the cedar strips together.

The canoe-wright sheathed the inside with long white cedar strips running lengthwise to form the bottom of the craft. On top bow shaped white cedar strips were placed in a series from gunwale to gunwale to form strong yet flexible ribs. After the bottom slats that lined the interior of the canoe were fixed in place, half circle frames of cedar were forced in place from end to end to establish stiffness to the craft.

Black spruce roots up to the thickness of a little finger were split into three or four parts and soaked in water to maintain their pliability for sewing the bark skin of the canoe to the frame. Two round beech bows approximately the thickness of a walking cane were bent in the form of the canoe gunwale then sewn together to the bark skin with the root lacings to form an inside gunwale rim. The ends were joined on both sides below those beech bow pieces that had been sewn around on the top of the canoe. When the frame was sown to the gunwales and the bark hull, the integrated unit was remarkably strong.

There were many seams because the bark cover had to be split, overlapped and sewn. Sticky spruce resin was collected and heated to thick syrup then cooled to a gumlike consistency. Women and girls had the task of chewing the spruce gum of the spruce until it became a soft saliva diluted salve. The salve was collected, desiccated into a pitch-glue material, and then applied to the seams and cracks as waterproofing. In some tribes animal fat was applied to the bark and gunwale lashings as supplemental waterproofing. For ocean-going vessels, bark covering was lashed over portions of the 
bow that acted as a small decking to minimize the shipping of water as the canoe encountered waves. ${ }^{8}$ The craft's thwarts and paddles were made from harder maple or ash. The paddles were about five feet long with a strengthening rib carved in relief running down its length and a knob or flare at the end of the handle.

The Penobscot tribe ranged through the northeastern Maine coast south, approximately to the current New Hampshire border. Their light canoes had low bows and sterns that were efficient in the calm waters of a land dotted with rivers and lakes as well as harbor outlets. High bows and sterns, similar to those of the Mi'kmaq, offered protection against waves and rough seas, but produced greater wind resistance making them more difficult to paddle in cross winds. Also these small lighter canoes were easier to use in portage and navigating in white water. The method of construction of the Penobscot canoes was similar to those of the Mi'kmaq.

The Malecite inhabited territory west and somewhat south of the Mi'kmaq roughly between the Mi'kmaq and Penobscot. The Malecite canoe design marked a transitional design between the Mi'kmaq and Penobscot types of crafts characterized by a flat bottom and less tumblehome than that of the Mi'kmaq. The bow was lower and presented less reverse sheer, but still had considerably more than Penobscot canoes. In general they were about eighteen feet in length with a beam of roughly thirty inches. The dead rise of the bow and stern was only about six inches with little or no tumblehome. ${ }^{9}$

Some canoes were decorated with colorful emblems made from natural plant dyes. These varied from personal marks of a builder or tribal signs of a warrior, but more often ritual or spiritual symbols designed to favorably influence animistic spirits common subjects of Native mythology such as the eagle or rabbit. ${ }^{10}$ Other designs called a "gogetch" were abstractions resembling curved plants such as the fiddlehead fern remarkably like a sailing ship's figurehead called a fiddlehead for its reverse curve known as a billet-head, plus circular cloud patterns, the moon or stars. These marks were frequently placed on the "wulegessis," the name of the Native protective bark covering below the gunwale lashings that ran the length of the vessel.

\section{Elm, Skin and Dugout Canoes}

The availability of suitable woods and wood byproducts was crucial in determining the type of vessel the canoe-wright could build. Because of the sparseness and small circumference of the birch trees, elm-bark canoes and dugouts were more common on the south shore of Massachusetts Bay southward to New York. Elm-bark canoes were heavy and difficult to maneuver as compared with bark canoes, but their construction was relatively easy often taking only about two hours. ${ }^{11}$

8 N. Denys, The Description and Natural History of the Coasts of North America, ed. W. F. Ganong (Toronto, Champlain Society, 1908), 420-422.

9 Wendell S. Hadlock and Ernest S. Dodge, "A Canoe From The Penobscot River," The American Neptune vol. VIII, no. 4 (1948).

10 Ibid., 82-88.

11 Regina Flannery, An Analysis of Coastal Algonquin Culture (Washington: Catholic University of America Press, 1939), 58-62. 
Dugouts were made from pine, cedar, and occasionally sycamore, cottonwood or chestnut often found near water. ${ }^{12}$ A Native or a group of Natives would go into the forest with tools and select a tree to be felled. By a combination of selective burning, placing mud on the edge as perimeter protection, dropping hot stones in a water basin formed in the tree, and gouging the detritus with shaped stones, moose antlers or shells, the dugout would be hollowed and shaped. Dugout canoes could be large enough to hold a party of ten or twelve men. Frequently they were made from burning a tree at its base until it was weakened, felled near the water's edge, hacked to the desired length, then stripped of bark and limbs. Wooden wedges or sharpened stone wedges called "celts" would be driven with wooden mauls under the bark to help shape the vessel. It was hollowed out by burning the upturned surface into the heart of the tree then removing the soft charcoal with seashells or stone scrappers shaped into an adze with a hardwood handle. The dimension of the thinner gunwales and thicker floor would be measured as finger widths. Some canoes were filled with water that was heated to near boiling by hot stones. The hot water softened the wooden gunwales and interior so they could be broadened by hammering in sturdy thwarts crosswise.

Modeling and refining could last from ten days for a small two man boat to more than two weeks to produce a boat capable of holding from three to forty people. ${ }^{13}$ According to the explorer Verrazzano, the Natives of Narragansett Bay "make their barges from the trunk of a single tree hollowed out in which [14-15] men will go comfortably, the short oar broad at one end working it solely with the strength of arms at sea without any peril with as much speed as pleases them." ${ }^{14}$ From evidence found in burial sites Monhegan Island Natives fished for swordfish from dugouts. ${ }^{15}$ These aggressive denizens often exceeded ten feet in length. They frequently attacked boats carrying fishermen apparently attempting to pierce the canoes with their sharp stout bills or swamp them with thrashing tails. Therefore the Native's white pine dugouts had to be extremely strong to withstand this assault.

Dugouts would crack during the winter if water seeped into the dried wood and froze. In order to avoid this fate the Natives filled the dugouts with stones and sunk them in ponds that froze in the winter. This would keep the wood wet and relatively deprived of oxygen so worms or termites could be controlled. The Natives would then retrieve them in the spring and dry them in the sun for another season of use.

Skin canoes were variations that appear to have been the most important with the

12 The Mariners Museum of Newport News VA displays a Powhatan dugout canoe (circa 1630) that is 26 feet in length, 2 feet and $11 / 4$ inches in beam width and 17 inches in depth. There are fire marks from its construction as well as adze marks that likely was added by AngloAmerican reuse.

13 Roger Williams, Key to the Indian Language (Collections of the Rhode Island Historical Society) (Providence, RI, 1827), vol. I, 98-99.

14 "Giovanni Da Verrazzano and His Discoveries In North America, 1524," in American Scenic and Historic Preservation Society (Albany, 1910), vol. 15, 192-193. 
Beothuk, Mi'kmaq and Malecite. ${ }^{16}$ When in need of a boat for short distance water travel the Native Americans would build "Canoes of Moose-Hides sewing three or four together and pitching the Seams with Charcoal beaten and mixed with Balsam." ${ }^{17}$ The hide-hair of the animal was usually, but not always removed. The skin covering held the framework together, unlike that used kayak construction. The resulting craft was called a "moosoolk."18 These canoes reached fifteen feet in length and two and a half feet in width. If tough moose hide was not available caribou or seal was substituted for stretching over a frame. The skins were sown in a lengthwise pattern and generously overlapped secured by double stitching of rawhide lacings. The seams were made watertight with a caulking material of tallow and gum. The bow and stern of these boats were occasionally reinforced with an overlay of spruce bark. The canoe was covered with a loose skin decking except where the paddler sat, somewhat resembling the closure of the kayak. In rough seas the mariner could wrap skins around him to form a weather seal skirt. These craft were used for offshore trips to catch seals and porpoises. ${ }^{19}$ A primitive variation of skin boats was the bull-boat, a bowl-shaped craft that was not a canoe, but a coracle for use in ponds and streams. These vessels were safe enough for close-to-shore fishing or for short-distance ferrying.

\section{Sailing Canoes}

Because of the design and construction of the Native craft, sails were seldom if ever used in the northeast before European contact. The exception was the Beothuks who occasionally carried a square sail on a stayed mast located amidships used in fair weather with a following breeze. ${ }^{20}$ All of the designs previously described were quite vulnerable to capsizing because they were flat-bottomed and lacked even a rudimentary keel. Although they might be capable of running with wind behind them, they could not effectively go toward the direction of the wind. Any attempt to use a sail in a bark canoe except for running in the mildest weather might have caused them either to capsize, broach, be torn apart from the strain of the mast, or be pushed leeward. The earliest European accounts of Native canoes made no mention of sails. During the midseventeenth and eighteenth century however, a few references to canoes and sails were noted. Natives of Narragansett Bay hoisted bits of clothing on a pole enabling them to run before the wind but, because they were not equipped with any type of leeboard, they could easily capsize in even a moderate breeze. ${ }^{21}$ In 1650 Denys noted that a canoe "went with sail [that] was formerly of bark but oftener of a well dressed moose skin. Had they a

16 Howley, Beothuks, 152. "They use the same type of skin canoes in the interior as others"; Silas Tertius Rand, Legends of the Micmacs (New York, 1894); Gyles, Memoirs.

17 Ibid., 10.

18 Mi’kmaq: “moose-ship.” Rand, Legends, 197

19 Frank G. Speck, Beothuk and Mi'kmaq (New York: Museum of the American Indian, Heye Foundation, 1922), 33-60.

20 Howley, Beothuk, 33.

21 Williams, Key to the Indian Language. (Verrazzano, a century earlier, noted that they paddled only with "the broad oar"). 
favorable breeze they went as swiftly as the throw of a stone." 22 These descriptions occurred decades after the Natives first had contact with Europeans and were probably influenced by the technology observed and a later copied after these encounters. ${ }^{23}$ Some years earlier, in May 1602 near the craggy Isles of Shoals off New Hampshire's coast, Gabriel Archer on the English vessel Concord made the following notation: "From said rock came towards us a Biscay [Basque] shallop with sayle [sail] and oars having eight persons in it, whom we first supposed to be Christians distressed. But approaching closer we perceived them to be savages . . .."24 They were asked where they were from and the Aboriginal mariners drew a crude charcoal drawing that appeared to be Placentia Bay, Newfoundland. This is evidence that by 1602 Native Americans had learned to propel and navigate a sophisticated substantial vessel over many miles of ocean. It is not known whether this was given to them in trade or more likely booty from a raid on a Basque fishing party.

\section{Conclusion}

Native American canoe-wrights were clever and resourceful using the availability of building materials that reflected their aboriginal cultures and animistic religions in the use and design of their watercraft. The canoe's styles and construction evolved over time, as did their skill working with far better tools. Although no pre-1500 Native vessels have been preserved and no written records exist concerning their building techniques, Aboriginal oral histories and descriptions of various crafts by European explorers and colonists provide inferences concerning the Native's methods and marine architecture. Many of the watercrafts that they produced with the implements and materials they had at hand could be considered technical works of wonder.

\section{Bibliography}

Beck, Horace P. The American Indian as a Sea Fighter in Colonial Times. Mystic, CT: Marine Historical Association, 1920.

Denys, N. The Description and Natural History of the Coasts of North America, Edited by W. F. Ganong. Toronto, 1908.

Documentary History of the State of Maine in Collections of The Maine Historical Society, series 2. Portland, 1900.

Duncan, Robert F. A Cruising Guide to the New England Coast. New York, 1938.

Flannery, Regina. An Analysis of Coastal Algonquin Cultures. Washington, 1939.

Gyles, John. Memoirs of Odd Adventures, Strange Deliverances, etc. in the Captivity of John Gyles. Boston, 1736.

Guy, Camil. The Weymontaching Birchbark Canoe. Ottawa, ON: National Museum of Canada, 1974.

22 Denys, Description and Natural History, 422.

23 It should be noted that the indigenous people of the Pacific coast of South America and the South Seas had sailing canoes long before they had contact with Europeans.

24 Henry F. Howe, Prologue to New England (New York: Farrar and Rinehart, 1946), 56. 
Howley, James P. The Beothucks or Red Indians. Cambridge, MA, 1915. Haven, CT, 1940.

Innis, Harold A. The Cod Fisheries: The History of an International Economy. New

Journal of American Folklore. Boston, Lancaster, PA, and New York, 1887.

Mason, John. Brief History of the Pequot War, Especially of the Taking of Their Fort at Mistick in Connecticut in 1673 etc. In Massachusetts Historical Society Collections, second series, vol. 8 .

Mason, O. T. “Aboriginal American Harpoons," Report of U.S. National Museum for 1900. Washington, DC 1900, 189-304.

Mechling, William H. Malecite Tales. Ottawa, 1914.

Parker, Arlita D. A History of Pemaquid with Sketches of Monhegan Popham and Castine. Boston, 1925.

Rand, Silas T. Legends of the Micmacs. New York, 1894.

Rowe, William H. Maritime History of Maine, Three Centuries of Shipbuilding and Seafaring. New York, 1948.

Salisbury, Neal. "The Indians' Old World: Native Americans and the Coming of Europeans." William and Mary Quarterly, third series LIII (July 1996), 435-58.

Smith, Captain John. A Description of New England. In Old South Leaflets, General Series, vol. 5, no.121. Boston: Old South Association, nd.

Speck, Frank G. Beothuk and Micmac. New York: Museum of the American Indian Heye Foundation, 1922. 1940. Penobscot Man: The Life History of a Forest Tribe in Maine. Philadelphia,

Winship, George P. Sailor's Narratives of Voyages along the New England Coast 1524-1624. Boston, 1905.

Winslow, Ola E. American Broadside Verse From Imprints of the 17th and I8th Centuries. New Haven, CT., 1930.

\section{Migration of Paleo-Indians and Archaic Indians:}

Fagan, Brian M. The Great Journey: The Peopling of Ancient America. London: Thames \& Hudson, 1987.

Beyond the Blue Horizon: How the Earliest Mariners Unlocked the Secretes of the Oceans. New York: Bloomsbury Press, 2012. 1992.

Fiedel, Stuart J. Prehistory of the Americas. New York: Cambridge University Press,

Snow, Dean R. "The First Americans and the Differentiation of Hunter Gatherer Cultures." In The Cambridge History of the Native Peoples of the Americas, vol. 1, North America, part I, edited by Bruce G. Trigger and Wilcomb E. Washburn, 125-200. New York: Cambridge University Press, 1996. 


\section{For the supernatural and environmental beliefs of native people:}

Hinderaker, Eric. Elusive Empires: Constructing Colonialism in the Ohio Valley, 1673-1800. New York: Cambridge University Press, 1997.

Josephy, Alvin M. Jr., ed. America in 1492: The World of the Indian Peoples Before the Arrival of Columbus. New York: Alfred A. Knopf, 1992.

Krech, Shepard, III, ed. Indians, Animals, and the Fur Trade: A Critique of Keepers of the Game. Athens: University of Georgia Press, 1981.

- The Ecological Indian: Myth and History. New York: W.W. Norton, 1999.

Salisbury, Neal. Manitou and Providence: Indians, Europeans, and the Making of New England, 1500-1643. New York: Oxford University Press, 1982.

White, Richard. The Organic Machine: The Remaking of the Columbia River. New York: Hill \& Wang, 1995.

Tanner, Adrian; Bringing Home Animals: Religious Ideology and Mode of Production of Mistassini Cree Hunters. New York: St. Martin Press, 1979.

For the spiritual ideas of Europeans and their economic and environmental implications:

Cronon, William. Changes in the Land: Indians, Colonists, and the Ecology of New England. New York: Hill \& Wang, 1983.

Innes, Stephen. Creating the Commonwealth: The Economic Culture of Puritan New England. New York: W. W. Norton, 1995.

Merchant, Carolyn. Ecological Revolutions: Nature, Gender, and Science in New England. Chapel Hill: University of North Carolina Press, 1989.

Silver, Timothy. A New Face on the Countryside: Indians, Colonists, and Slaves in South Atlantic Forests, 1500-1800. New York: Cambridge University Press, 1990.

\section{For the Indians of New England:}

Bragdon, Kathleen J. Native People of Southern New England, 1500-1650. Norman: University of Oklahoma Press, 1996.

Hauptman Laurence M. and James D. Wherry, James D., eds. The Pequots in Southern New England. The Fall and Rise of an American Indian Nation. Norman: University of Oklahoma Press, 1990.

Simmons, William S. Spirit of the New England Tribes: Indian History and Folklore, 1620-1984. Hanover, NH : University Press of New England, 1986.

For the economic culture of the colonists and the environmental transformation of New England:

Cronon, William. Changes in the Land: Indians, Colonists, and the Ecology of New England. New York: Hill and Wang, 1983.

Innes, Stephen. Creating the Commonwealth: The Economic Culture of Puritan New 
England. New York: W. W. Norton, 1995.

Merchant, Carolyn. Ecological Revolutions: Nature, Gender, and Science in New England. Chapel Hill: University of North Carolina Press, 1989.

\section{Miscellaneous Native watercraft references:}

Adney, Edwin Tappan and Howard I. Chapelle. Bark Canoes and Skin Boats of North America. Washington: The Smithsonian Institution, 1964.

Gidmark, David. Building a Birch Bark Canoe: The Algonquin Wâbanäki Tcîmân. Richmond Hill, ON: Firefly Books, 2002. 2002.

Jennings, John. The Canoe: A Living Tradition. Richmond Hill, ON: Firefly Books, Firefly Books, 2004.

Pulling, Pierre and Hap Gilliland. Indian Canoeing. Billings, Montana: Council for Indian Education, 1976.

Roberts, Kenneth and Phillip Shackleton. Canoe: A History of the Craft from Panama to the Arctic. Camden, ME: International Marine Publishing, 1983.

\section{General works:} author, 1985.

Cook, David S. Above the Gravel Bar: Indian Canoe Routes of Maine. Published by

Gookin, Daniel (1612-1687). Historical Collections of Indians in New England. 1792. Reprint, Boston: Belknap and Hall, 1972.

- Historical Account of the Doings and Sufferings of Christian Indians in New England in the Years 1675, 1676, and 1677. Reprint, New York: Arno Press, 1972.

Hubbard, Lucius. Woods and Lakes of Maine: A Trip from Moosehead Lake to New Brunswick in a Birch-Bark Canoe. Boston: J. R. Osgood and Company, 1884.

McPhee, John A. The Survival of the Bark Canoe. New York: Farrar, Straus, Giroux, 1975. [Native watercraft in Maine.]

Williams, Roger (1604-1683). The Correspondence of Roger Williams. Edited by Glenn W. LaFantasie, Robert S. Cocroft, Bradford F. Swan, et al. Providence, RI: Rhode Island Historical Society, 1988.

Wood, William. New England's Prospect. 1639. Reprint, Amherst, MA: University of Massachusetts Press, 1993. 
